\title{
ACUTE COMPARTMENT SYNDROME
}

\author{
EFFECT OF DERMOTOMY ON FASCIAL DECOMPRESSION IN THE LEG
}

\author{
MARK S. COHEN, STEVEN R. GARFIN, ALAN R. HARGENS, SCOTT J. MUBARAK
}

\author{
From the University of California, San Diego
}

\begin{abstract}
Prompt surgical decompression is the only means of preventing the late sequelae of ischaemic contracture in post-traumatic compartment syndromes. However, controversy exists regarding the length of dermotomy required for adequate decompression in the lower extremity. This study investigated the skin envelope as a potential contributing factor.

Wide fascial releases were performed through limited $8 \mathrm{~cm}$ incisions in eight cases of post-traumatic lower extremity compartment syndrome. In nine of 29 compartments the pressure remained greater than $30 \mathrm{mmHg}$. Lengthening the skin incisions to an average of $16 \mathrm{~cm}$ decreased intracompartmental pressures significantly.

This study documents the skin envelope as a contributing factor in acute compartment syndromes of the leg. The use of generous skin incisions is supported and the need for intra-operative compartment pressure measurements in the treatment of this condition is emphasised.
\end{abstract}

Prompt fascial release is the recognised treatment for acute compartment syndromes. However, controversy exists regarding the length of dermotomy required for adequate decompression in the lower extremity. Some authors have favoured limited incisions, claiming low morbidity as an advantage (Patman, Poulos and Shires 1964; Rosato et al 1966; Gaspar et al 1968; Bate 1972; Gaspard, Cohen and Gaspar 1972; Patman, Thompson and Persson 1973; Gaspard and Kohl 1975; Patman 1975; Hoopes and Maxwell 1979). Others have stated that long skin incisions are required to decompress affected compartments adequately (Mubarak and Owen 1977; Matsen, Winquist and Krugmire 1980; DeLee and Stiehl 1981; Rollins, Bernhard and Towne 1981; Hyde, Peck and Powell 1983; Mubarak and Hargens 1983; Bess 1984; Rorabeck 1984; Blick et al 1986; Noble and Banks 1986). Several instances in which the skin continued to cause compression after fasciotomy through short incisions have been reported (Gaspard et al 1972; Gaspard

M. S. Cohen, MD, Resident in Orthopaedics

S. R. Garfin, MD, Professor of Orthopaedic Surgery

S. J. Mubarak, MD, Clinical Instructor of Orthopaedic Surgery

Division of Orthopaedics, University of California, 225 Dickinson Street, San Diego, California 92103, USA.

A. R. Hargens, PhD, Space Station Project Scientist

Space Physiology Branch 239-17, NASA, Ames Research Center, Moffett Field, California 94035, USA.

Correspondence should be sent to Dr S. R. Garfin.

(C) 1991 British Editorial Society of Bone and Joint Surgery 0301-620X/91/2075\$2.00

J Bone Joint Surg [Br] 1991 ; 73-B :287-90. and Kohl 1975), but measurements of intracompartmental pressure were not recorded in these cases.

This study was undertaken to determine the effect of the length of the skin incision in post-traumatic compartment syndromes of the lower extremity treated by fascial decompression. Intracompartmental pressures were measured using a wick catheter, which is known to give reliable and reproducible measurements (Mubarak et al 1976, 1978; Koman, Hardaker and Goldner 1981; Russell, Apyan and Burns 1985).

\section{MATERIALS AND METHODS}

Eight patients with lower extremity compartment syndromes were studied; their ages ranged from 19 to 64 years (mean 34). All had suspected compartment syndromes following lower extremity trauma. Pressure measurements were made using a wick catheter (Cutter Biomedical, San Diego). The indications for pressure measurements were painful swelling of the limb and a palpably tense compartment, usually with distal hypoaesthesia (Mubarak et al 1978; Mubarak 1984). An intracompartmental pressure greater than $30 \mathrm{mmHg}$ was recorded in all patients. We and others have chosen this pressure as an indication for decompressive fasciotomy (Mubarak and Owen 1977; Mubarak et al 1978; Saffle, Zeluff and Warden 1980; Koman et al 1981; Hyde et al 1983; Bess 1984; Rorabeck 1984; Russell et al 1985; Blick et al 1986; Gershuni et al 1987; Siverhus and Amis 1988; Vitale et al 1988).

The injuries associated with the compartment 
syndromes were: closed proximal fracture of the tibia (with or without fibular fracture) in four patients; bilateral fibular fractures in one; a low velocity gunshot injury in one; and closed trauma to the leg without fracture in one patient with haemophilia.

Surgical decompression of the leg was performed using the double-incision technique, which employs an anterolateral and a posteromedial incision (Dennis 1945; DeBakey and Simeone 1946; Mubarak and Owen 1977) (Fig. 1). All affected osteofascial compartments were initially released through $8 \mathrm{~cm}$-long skin incisions. Such incisions were considered adequate to allow complete proximal and distal fascial release. After the fasciotomy the compartment pressures were again measured. The pressure was recorded when equilibrium had been reached, usually five to 10 minutes after fasciotomy.

The anterolateral skin incision was then enlarged, in $2 \mathrm{~cm}$ increments, and the pressure was recorded after each extension until the readings showed no further change. The dermotomy extensions were necessarily performed without undue delay, to avoid the adverse effects of prolonged elevation of the intracompartmental pressure.

The posteromedial incision was enlarged only if the pressure in the posterior compartment was greater than or near to the critical level of $30 \mathrm{mmHg}$ (25 to 30 ).

In all cases the fascial release performed through the limited skin incisions was adequate and at no time was additional incision of the fascia required during the extension of the dermotomies.

The compartment pressures before and after lengthening the skin incisions were compared using the paired Student's $t$-test.

\section{RESULTS}

The results are given in Table I. Pre-operatively, all patients had pressure greater than $30 \mathrm{mmHg}$ in at least one compartment (mean $48 \mathrm{mmHg}, \mathrm{SD} \pm 12$ ). Following

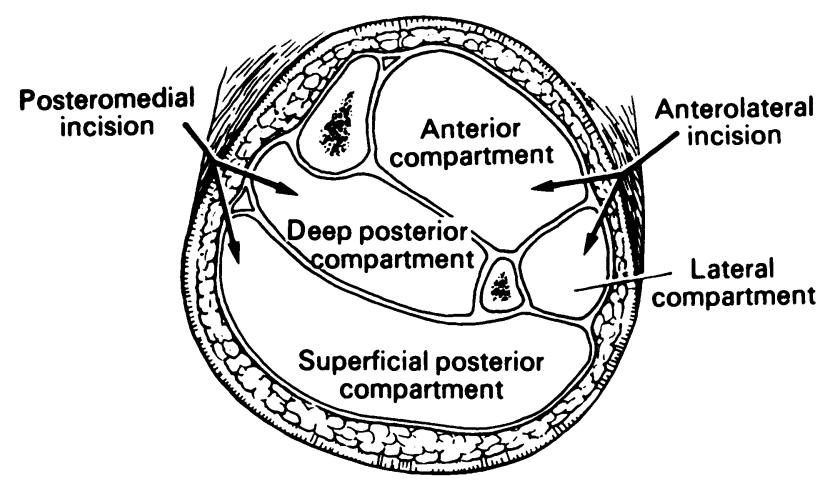

Fig. 1

Cross-section at the level of the middle and distal thirds of the leg to illustrate decompression of the four fascial compartments using the double-incision technique. fascial release, through the limited $8 \mathrm{~cm}$ incisions, the compartment pressures decreased to a mean $25 \mathrm{mmHg}$, $\mathrm{SD} \pm 11$.

However, in nine of 29 compartments the pressure remained above $30 \mathrm{mmHg}$. Four of these compartments were anterior, four lateral, and one was a deep-posterior compartment.

The anterolateral skin incisions were extended in them all and the posteromedial incisions in three. The final length of the extended incisions averaged $16 \mathrm{~cm} \pm$ 4. The mean final pressure in the compartments which required extended incisions was $13 \mathrm{mmHg}, \mathrm{SD} \pm 6$. This was significantly less than the mean pressure recorded in these compartments before the skin incisions were extended ( $\mathrm{p}<0.002$, Fig. 2).

\section{DISCUSSION}

Prompt surgical decompression is the only means of preventing the late sequelae of ischaemic contracture in post-traumatic compartment syndrome. In circumferential burns of the limbs, the skin is recognised to be the primary constricting envelope, and generous escharotomy is the treatment of choice (Kaplan and White 1961; Pruitt, Dowling and Moncrief 1968; Asch, Flemma and Pruitt 1969; Justis, Law and MacMillan 1976; Saffle et al 1980). However, in the traumatised limb, it is the strong fascial compartment boundaries which are the least responsive to internal pressure gradients, and all authors agree on the need for wide fascial release. Controversy exists only with regard to the length of the skin incisions.

The proponents of limited dermotomy $(4$ to $8 \mathrm{~cm}$ ) cite as advantages a decreased risk of infection, shorter

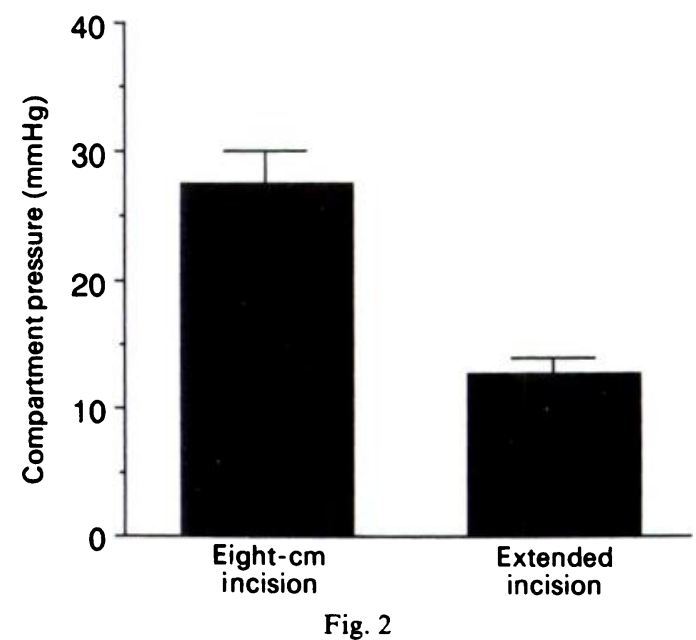

Pressure measurements (mean + SEM) in 21 lower extremity compartments initially treated by fascial decompression through limited $8 \mathrm{~cm}$ incisions. Extension of the skin incisions to a mean of $16 \mathrm{~cm}$ resulted in a significant decrease in compartment pressures $(\mathrm{p}<0.002)$. 
healing time, better scars, and easier secondary wound closure. Long incisions have been said to cause more bleeding and to prejudice the distal circulation in the limb by damaging collateral vessels (Patman et al 1973; Patman 1975).

Others have recommended long skin incisions ( 15 to $30 \mathrm{~cm}$ ) in all cases, using either a single lateral incision (Matsen and Clawson 1975; Nghiem and Boland 1980; DeLee and Stiehl 1981; Rollins et al 1981) or a double-
Long skin incisions are stated to add little to the morbidity and they eliminate the risk of the skin acting as an unrecognised compartment envelope. This is especially important in the hyperaemic period following decompression of an ischaemic compartment (Matsen and Clawson 1975; Whitesides et al 1977; Matsen et al 1980).

Sheridan and Matsen (1976) reviewed 46 cases of upper and lower extremity compartment syndrome treated either by 'open' fasciotomy (31 limbs) or 'closed'

Table I. Details of pressure measurements in eight patients with compartment syndrome

\begin{tabular}{|c|c|c|c|c|c|c|c|}
\hline \multirow[b]{2}{*}{ Case } & \multirow[b]{2}{*}{$\begin{array}{l}\text { Age/ } \\
\text { Sex }\end{array}$} & \multirow[b]{2}{*}{ Injury } & \multirow[b]{2}{*}{ Compartment* } & \multicolumn{3}{|c|}{ Pressure in $\mathbf{m m H g}$} & \multirow[b]{2}{*}{$\begin{array}{l}\text { Final length of } \\
\text { skin incision }(\mathrm{cm})\end{array}$} \\
\hline & & & & $\begin{array}{l}\text { Before } \\
\text { operation }\end{array}$ & $\begin{array}{l}\text { After fasciotomy } \\
\text { through 8-cm } \\
\text { skin incision }\end{array}$ & $\begin{array}{l}\text { After extension } \\
\text { of skin incision }\end{array}$ & \\
\hline 1 & $19 / \mathrm{M}$ & $\begin{array}{l}\text { Closed fibular } \\
\text { fracture }\end{array}$ & $\begin{array}{c}\text { ANT } \\
\text { LAT } \\
\text { SP } \\
\text { DP }\end{array}$ & $\begin{array}{l}50 \\
55 \\
45 \\
55\end{array}$ & $\begin{array}{l}37 \\
35 \\
10 \\
17\end{array}$ & $\begin{array}{l}20 \\
20\end{array}$ & $\begin{array}{r}14 \\
8\end{array}$ \\
\hline 2 & 19/M & $\begin{array}{l}\text { Closed fibular } \\
\text { fracture }\end{array}$ & $\begin{array}{c}\text { ANT } \\
\text { LAT } \\
\text { SP } \\
\text { DP }\end{array}$ & $\begin{array}{l}46 \\
40 \\
50 \\
55\end{array}$ & $\begin{array}{l}34 \\
37 \\
22 \\
22\end{array}$ & $\begin{array}{l}21 \\
16\end{array}$ & $\begin{array}{r}16 \\
8\end{array}$ \\
\hline 3 & $47 / F$ & Soft-tissue & $\begin{array}{c}\text { ANT } \\
\text { LAT } \\
\text { SP } \\
\text { DP }\end{array}$ & $\begin{array}{l}75 \\
60 \\
20 \\
55\end{array}$ & $\begin{array}{l}35 \\
24 \\
15 \\
10\end{array}$ & $\begin{array}{r}9 \\
4 \\
7 \\
20\end{array}$ & $\begin{array}{l}24 \\
14\end{array}$ \\
\hline 4 & $64 / M$ & $\begin{array}{l}\text { Closed proximal } \\
\text { tibial fracture }\end{array}$ & $\begin{array}{c}\text { NT } \\
\text { LAT } \\
\text { SP } \\
\text { DP }\end{array}$ & $\begin{array}{l}65 \\
55 \\
45 \\
55\end{array}$ & $\begin{array}{r}5 \\
25 \\
18 \\
21\end{array}$ & $\begin{array}{r}5 \\
10\end{array}$ & $\begin{array}{r}12 \\
8\end{array}$ \\
\hline 5 & $26 / F$ & $\begin{array}{l}\text { Closed proximal } \\
\text { tibial/fibular } \\
\text { fracture }\end{array}$ & $\begin{array}{c}\text { ANT } \\
\text { LAT } \\
\text { SP } \\
\text { DP }\end{array}$ & $\begin{array}{l}35 \\
35 \\
45 \\
50\end{array}$ & $\begin{array}{l}20 \\
16 \\
26 \\
28\end{array}$ & $\begin{array}{l}15 \\
10 \\
20 \\
12\end{array}$ & $\begin{array}{l}12 \\
12\end{array}$ \\
\hline 6 & $36 / M$ & $\begin{array}{l}\text { Closed proximal } \\
\text { tibial fracture }\end{array}$ & $\begin{array}{c}\text { ANT } \\
\text { LAT } \\
\text { SP } \\
\text { DP }\end{array}$ & $\begin{array}{l}65 \\
55 \\
30 \\
35\end{array}$ & $\begin{array}{l}45 \\
32 \\
16 \\
22\end{array}$ & $\begin{array}{l}17 \\
12\end{array}$ & $\begin{array}{r}18 \\
8\end{array}$ \\
\hline 7 & $28 / M$ & $\begin{array}{l}\text { Low-velocity } \\
\text { gunshot }\end{array}$ & $\begin{array}{c}\text { ANT } \\
\text { LAT } \\
\text { SP } \\
\text { DP }\end{array}$ & $\begin{array}{l}60 \\
- \\
- \\
-\end{array}$ & $\begin{array}{l}18 \\
- \\
-\end{array}$ & 7 & 14 \\
\hline 8 & $14 / M$ & $\begin{array}{l}\text { Closed proximal } \\
\text { tibial/fibular } \\
\text { fracture }\end{array}$ & $\begin{array}{c}\text { ANT } \\
\text { LAT } \\
\text { SP } \\
\text { DP }\end{array}$ & $\begin{array}{l}50 \\
50 \\
30 \\
32\end{array}$ & $\begin{array}{l}26 \\
36 \\
10 \\
25\end{array}$ & $\begin{array}{r}8 \\
18 \\
6 \\
9\end{array}$ & $\begin{array}{l}20 \\
16\end{array}$ \\
\hline
\end{tabular}

* fascial compartments: ANT, anterior; LAT, lateral; SP, superficial posterior; DP, deep posterior

incision technique (Dennis 1945; Mubarak and Owen 1977; Whitesides, Harada and Morimoto 1977; Hyde et al 1983; Mubarak and Hargens 1983; Rorabeck 1983; Bess 1984; Blick et al 1986; Noble and Banks 1986). These authors thought that long incisions were necessary to allow adequate inspection and decompression of the compartments of the leg. A long anterolateral incision may also minimise the risk of injury to the superficial peroneal nerve, and a long posteromedial incision provides better access to the deep posterior compartment. fasciotomy (15 limbs). The size of the dermotomy was found to influence neither the complication rate nor the late functional result. However, the two groups were not strictly comparable and intracompartmental pressures were not measured. Gaspard et al (1972) described two patients with lower extremity compartment syndromes who failed to improve clinically, despite adequate fasciotomies through limited incisions $(5 \mathrm{~cm})$. Both responded favourably to wide dermotomies of the calf.

Our study confirms that the skin is a potential 
contributing factor in compartment syndrome. Though wide fascial releases were carried out in all patients, nine of 29 compartments remained under pressures greater than $30 \mathrm{mmHg}$. Lengthening the skin incisions significantly decreased the pressures.

Though we cannot predict what would have been the outcome in the limbs with 'limited' dermotomies, this study documents the potential contribution of the skin envelope in lower extremity compartment syndrome. The use of generous skin incisions is supported and the need for intra-operative measurement of the compartment pressures in the treatment of this condition is emphasised.

The authors wish to thank Kathy Edwards for typing and preparing the manuscript.

No benefits in any form have been received or will be received from a commercial party related directly or indirectly to the subject of this article.

\section{REFERENCES}

Asch MJ, Flemma RJ, Pruitt BA, Jr. Ischemic necrosis of tibialis anterior muscle in burn patients: report of three cases. Surgery $1969 ; 66: 846-9$.

Bate JT. A subcutaneous fasciotome: an instrument for relief of compression in anterior, lateral, and posterior compartments of the leg from trauma and other causes. Clin Orthop 1972; 83:235-6.

Bess RJ. Fasciotomy. In: Moore EE, Eiseman B, Van Way CW, III, eds. Critical decisions in trauma. St Louis, etc: CV Mosby Co, 1984:530-1.

Blick SS, Brumbach RJ, Poka A, Burgess AR, Ebraheim NA. Compartment syndrome in open tibial fractures. J Bone Joint Surg [Am] 1986; 68-A :1348-53.

DeBakey ME, Simeone FA. Battle injuries of the arteries in World War II: an analysis of 2471 cases. Ann Surg 1946; 123:534-79.

DeLee JC, Stiehl JB. Open tibia fracture with compartment syndrome. Clin Orthop 1981; 160:175-84.

Dennis C. Disaster following femoral vein ligation for thrombophlebitis relief by fasciotomy; clinical case of renal impairment following crush injury. Surgery 1945; 17:264-9.

Gaspar MR, Treiman RL, Payne JH, Rothachild PD, Gaspard DJ. Principles of treatment and special problems in vascular trauma. Surg Clin N Am 1968; 48:1355-64.

Gaspard DJ, Cohen JL, Gaspar MR. Decompression dermotomy: a limb salvage adjunct. JAMA 1972; 220:831-3.

Gaspard DJ, Kohl RD Jr. Compartmental syndromes in which the skin is the limiting boundary. Clin Orthop 1975; 113:65-8.

Gershuni DH, Mubarak SJ, Yaru NC, Lee YF. Fracture of the tibia complicated by acute compartment syndrome. Clin Orthop 1987; 217:221-7.

Hoopes JE, Maxwell GP. Soft tissue injuries of the extremities. In: Zuidema GD, Rutherford RB, Ballinger WF II, eds. The Management of Trauma. 3rd Ed. Philadelphia: WB Saunders Co, 1979:522-60.

Hyde GL, Peck D, Powell DC. Compartment syndromes: early diagnosis and bedside operation. Amer Surg 1983; 49:563-8.

Justis DL, Law EJ, MacMillan BG. Tibial compartment syndromes in burn patients: a report of four cases. Arch Surg 1976; 111 :1004-8.

Kaplan I, White WL. Incisional decompression of circumferential burns. Plast Reconstr Surg 1961 ; 28:609-18.
Koman LA, Hardaker WT Jr, Goldner JL. Wick catheter in evaluating and treating compartment syndromes. So Med J 1981; 74:303-9.

Matsen FA III, Clawson DK. The deep posterior compartmental syndrome of the leg. J Bone Joint Surg [Am] 1975; 57-A:34-9.

Matsen FA III, Winquist RA, Krugmire RB Jr. Diagnosis and management of compartmental syndromes. J Bone Joint Surg [ Am] $1980 ; 62-A: 286-91$.

Mubarak SJ. Recognition and treatment of compartment syndromes. In: Meyers MH, ed. The multiply injured patient with complex fractures. Philadelphia: Lea and Febiger, 1984:71-89.

Mubarak SJ, Hargens AR. Acute compartment syndromes. Surg Clin $N$ Amer 1983; 63:539-65.

Mubarak SJ, Hargens AR, Owen CA, Garetto LP, Akeson WH. The Wick catheter technique for measurement of intramuscular pressure: a new research and clinical tool. J Bone Joint Surg [Am] 1976; 58-A:1016-20.

Mubarak SJ, Owen CA. Double-incision fasciotomy of the leg for decompression in compartment syndromes. J Bone Joint Surg [Am] 1977; 59-A:184-7.

Mubarak SJ, Owen CA, Hargens AR, Garetto LP, Akeson WH. Acute compartment syndromes: diagnosis and treatment with the aid of the wick catheter. J Bone Joint Surg [Am] 1978; 60-A:1091-5.

Nghiem DD, Boland JP. Four-compartment fasciotomy of the lower extremity without fibulectomy: a new approach. Amer Surg 1980; 46:414-7.

Noble J, Banks AJ. Emergency treatment of closed and compound fractures of the extremities. In: Dudley HAF, ed. Hamilton Bailey's emergency surgery. 11 th ed. Bristol: Wright, 1986:612-3.

Patman RD. Compartmental syndrome in peripheral vascular surgery. Clin Orthop 1975; 113:103-10.

Patman RD, Poulos E, Shires GT. The management of civilian arterial injuries. Surg Gynecol Obstet 1964; 118:725-38.

Patman RD, Thompson JE, Persson AV. Use and technic of fasciotomy as an adjunct to limb salvage. South Med J 1973; 66:1108-16.

Pruitt BA, Dowling JA, Moncrief JA. Escharotomy in early burn care. Arch Surg 1968; $96: 502-7$.

Rollins DL, Bernhard VM, Towne JB. Fasciotomy: an appraisal of controversial issues. Arch Surg 1981; 116:1474-81.

Rorabeck CH. A practical approach to compartmental syndromes. Part III. Management. In: AAOS Instructional Course Lectures. Vol 32. Chapter 5. St Louis, etc: CV Mosby, 1983:102-13.

Rorabeck CH. The treatment of compartment syndromes of the leg. $J$ Bone Joint Surg [ Br] 1984; 66-B:93-7.

Rosato FE, Barker CF, Roberts B, Danielson JK. Subcutaneous fasciotomy: description of a new technique and instrument. Surgery 1966; 59:383-6.

Russell WL, Apyan PM, Burns RP. Utilization and wide clinical implementation using the Wick catheter for compartment pressure measurement. Surg Gynecol Obstet 1985; 160:207-10.

Saffie JR, Zeluff GR, Warden GD. Intramuscular pressure in the burned arm: measurement and response to escharotomy. Am J Surg 1980; $140: 825-31$.

Sheridan GW, Matsen FA. Fasciotomy in the treatment of the acute compartment syndrome. J Bone Joint Surg [Am] 1976; 58-A: $112-5$.

Siverhus SW, Amis JA. A practical guide to acute compartment syndromes. J Musculoskel Med 1988; 5:88-103.

Vitale GC, Richardson JD, George SM Jr, Miller FB. Fasciotomy for severe, blunt, and penetrating trauma of the extremity. Surg Gynecol Obstet 1988; 166:397-401

Whitesides TE, Harada H, Morimoto K. Compartment syndromes and the role of fasciotomy, its parameters, and techniques. In: AAOS Instructional Course Lectures. Vol. 26. St Louis, etc: CV Mosby, 1977:179-94. 